\begin{tabular}{|c|c|c|c|c|c|}
\hline & \multicolumn{3}{|c|}{$\begin{array}{l}\text { Blackburn Elberta } \\
\text { from Wedderburn, } \\
\text { N.S.W. }\end{array}$} & \multirow{2}{*}{$\begin{array}{c}\text { J. H. Hale } \\
\text { from } \\
\text { Bathurst, } \\
\text { N.S.W., } \\
1950\end{array}$} & \multirow{2}{*}{$\begin{array}{l}\text { Golden } \\
\text { Queen from } \\
\text { Leeton, } \\
\text { N.S.W., } \\
1950\end{array}$} \\
\hline & 1950 & 1951 & 1952 & & \\
\hline $\begin{array}{l}\text { Quinic } \\
\text { Malic } \\
\text { Citric } \\
\text { Phosphoric } \\
\text { Others }\end{array}$ & $\begin{array}{r}28 \\
40 \\
25 \\
5 \\
2\end{array}$ & $\begin{array}{c}40 \\
30 \\
22 \\
4 \\
4^{*}\end{array}$ & $\begin{array}{l}38 \\
20 \\
36 \\
\text { 表 } \\
5\end{array}$ & $\begin{array}{r}18 \\
47 \\
28 \\
5 \\
2\end{array}$ & $\begin{array}{r}16 \\
64 \\
12 \\
5 \\
3\end{array}$ \\
\hline
\end{tabular}

The acids from three varieties of peaches grown in different locations, and from Blackburn Elberta peaches taken from the same orchard in three successive years, were separated as described. There was a considerable proportion of quinic acid in all the samples, and it was the major acid in one sample of Blackburn Elberta (see Table 1). All the peaches used were eating-ripe; some samples of less mature peaches will be tested next summer.

The two solvent mixtures mainly used for paper chromatography were alcohol - ammonia - water ${ }^{7}$ and methyl ethyl ketone - cineole - formic acid - water $(50: 50: 20: 16 \mathrm{v} / \mathrm{v})$. Cineole was used to hasten the removal of formic acid ${ }^{8}$, and methyl ethyl ketone, in place of an alcohol, to avoid the difficulties caused by esterification. The separation of the acids (see photograph) was as good as that obtained with other solvent mixtures. A similar mixture containing mesityl oxide ${ }^{9}$ gave very low $R_{F}$ values. A permanent record of the acid spots was obtained by spraying with glucose and silver nitrate ${ }^{10}$, and then fixing the paper with 1 per cent sodium thiosulphate.

$$
\text { E. F. L. J. ANET }
$$

T. M. Reynolds

Division of Food Preservation and Transport, Commonwealth Scientific and

Industrial Research Organization,

Homebush, N.S.W. Aug. 20.

I Winton, A. L., and Winton, K. B., "Structure and Composition of Foods", 2 (John Wiley and Sons, New York, 1935).

2 Peynaud, E., C.R. Acad. Sci., Paris, 232, 2474 (1951).

${ }^{3}$ Hulme, A. C., and Swain, T., Nature, 168, 254 (1951).

"Hulme, A. C., J. Exp. Bot., 2, 298 (1951).

${ }^{5}$ Partridge, S. M., and Brimley, R. C., Biochem. J., 51, 628 (1952).

6 Pigman, W. W. and Goepp, R. M.. "Chemistry of the Carbohydrates", 270 (Academic Press, Inc., New York. 1948).

${ }^{7}$ Long, A. G., Quayle, J. R., and Stedman, R. J., J. Soc. Chem., 2197 (1951).

${ }^{8}$ Cheftel, R., Munier, R., and Macheboeuf, M., Bull. Soc. Chim. Biol., 33,840 (1951).

' Lugg, J. W. H., and Overell, B. T., Aust. J. Sci. Res., A, 1, 98 (1948).

20 Gore, D. N., Chem. and Indust., 479 (1951).

\section{Seasonal Variation in the Regeneration of Root-Cuttings}

THE recent publication of Hudson ${ }^{1}$ recording an annual fluctuation of regenerating capacity in raspberry root-cuttings is paralleled by a number of observations on root-cuttings of horse-radish (Armoracia rusticana) made incidentally in this Department in the course of other work. These observations indicate that under constant conditions horse-radish cuttings show a seasonal variation in regenerating capacity, expressed as the mean number of primordia formed per root-scar in 10-14 days (Fig. 1). The results shown are at present incomplete, but it is hoped to extend them in the future. The point of particular interest, however, is that the regenerating capacity is low during the months of flowering (in Armoracia, during May and June); and an inspection

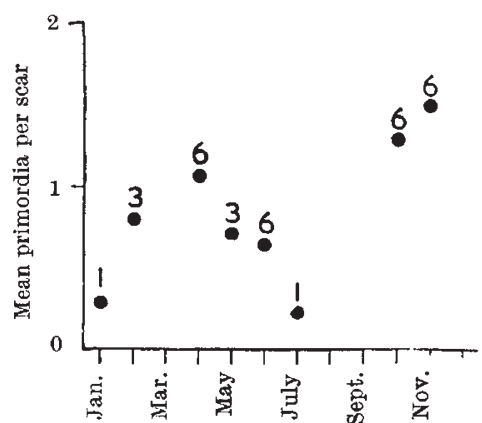
Fig. 1. Seasonal variation in the regeneration of horse-radish
root-cuttings. Figures represent number of experiments on root-cuttings. Figures represent number

of Hudson's graph shows that the same relationship holds for the raspberry (flowering June to August).

Examination of a propagation table given by Graham ${ }^{2}$ shows that of twelve species, all regenerating from the roots in the same manner as horse-radish and raspberry, five regenerate most efficiently before flowering, three after flowering, two regenerate most efficiently in the flowering month and also in another month, and two regenerate efficiently only during the flowering months. Similarly, of twelve species which regenerate from stem cuttings, five regenerate most efficiently before flowering, five most efficiently after flowering, and only two actually during flowering.

It is apparent that the antagonism between regenerating capacity and flowering is quite wide. spread and, apart from its possible biochemical implications, may have an important bearing on competition and survival in such plants.

\section{J. Dore}

Department of Botany, University of Southampton. Nov. 2.

: Hudson, J. P., Nature, 172, 412 (1953). ${ }^{2}$ Graham, R. J. D., Sci. Hort., 4, 97 (1936).

\section{Sperm Storage and Cross-Fertilization of Spring and Autumn Spawning Herring}

THrs preliminary communication gives the results of some experiments conducted at the Marine Laboratory, Aberdeen, in 1953, as part of a more extensive herring-rearing programme. They show that it is possible to cross-fertilize the two spawning 'types' of herring (Clupea harengus) found in the north-east Atlantic, one of which spawns in the spring, the other in the autumn.

To achieve this, a technique of long-term gamete storage is required. Polge, Smith and Parkes ${ }^{1}$ first reported that fowl spermatozoa stored in dilute glycerol at $-79^{\circ} \mathrm{C}$. remained alive for as long as nine months; Polge and Rowson ${ }^{2}$ found that bull spermatozoa remained fertile after storage for nine months under these conditions. Similar methods were therefore applied to the storage of herring gametes.

Ripe spermatozoa and eggs were obtained in March 1953 from spring-spawning herring caught in the Firth of Clyde. Two samples of each of the ovary and testes were removed by dissection and placed in sealed tubes containing a solution of 12.5 per cent glycerol in diluted sea water (one part distilled water to four parts sea water). After an interval of thirty minutes at a temperature of about $8^{\circ} \mathrm{C}$., one sample of each was frozen rapidly by placing it in solid carbon dioxide $\left(-79^{\circ} \mathrm{C}\right.$.). The other two samples were cooled slowly by immersing 